\title{
MENINGKATKAN HASIL BELAJAR SEJARAH MELALUI PENERAPAN MODEL PEMBELAJARAN TALKING STICK PADA SISWA KELAS XI IPS 3 SMA NEGERI 1 PENYABUNGAN
}

\author{
Muhammad Nuh \\ Guru SMA Negeri 1 Panyabungan \\ Surel : muhammad_nuh@gmail.com
}

\begin{abstract}
Abstrak
Penerapan model pembelajaran talking stick pada pembelajaran sejarah dapat membuat siswa untuk aktif berbicara dan berani mengemukakan pendapat. Penelitian ini bertujuan untuk meningkatkan hasil belajar siswa dengan menerapkan Model Pembelajaran Talking Stick. Melalui penerapan model pembelajaran kooperatif Talking Stick diperoleh hasil belajar siswa dari siklus ke siklus berikutnya mengalami peningkatan. Pada siklus I, peneliti melakukan pretes dan hanya 3 orang siswa yang nilainya melampaui KKM $\geq 78$ dengan nilai rata rata 61,14 dan ketuntasan klasikal yaitu 9\%. Kemudian peneliti melakukan tes Formatif I (Postes I) pada siklus I menunjukkan ketuntasan individunya sebanyak 20 orang dengan tuntas kelasikal sebesar $57,14 \%$ dan rata - rata nilai tes sebesar 73,71. Pada siklus II atau Formatif II menunjukkan hasil ketuntasan belajar individu sebanyak 30 orang dengan nilai ketuntasan klasikalnya sebesar 85,71\%.
\end{abstract}

Kata Kunci : Model, Talking Stick, Hasil Belajar

\section{PENDAHULUAN}

Pendidikan merupakan modal dasar bagi manusia untuk menjalani berbagai aktivitas yang bermanfaaat dalam kehidupannya. Supaya pembangunan bangsa semakin meningkat, dibutuhkan sumber daya manusia yang baik pula untuk menunjang pelaksanaannya. Salah satu upaya yang dapat dilakukan untuk meningkatkan sumber daya manusia adalah peningkatan mutu pendidikan, baik prestasi belajar siswa maupun kemampuan guru dalam melaksanakan proses pembelajaran. Peningkatan mutu pendidikan diarahkan pada semua bidang / ilmu pendidikan demi meningkatkan kualitas manusia seutuhnya. Sejarah merupakan pelajaran yang menanamkan pengetahuan dan nilai - nilai mengenai proses perubahan dan perkembangan masyarakat Indonesia dan dunia dari masa lampau hingga masa kini.

Lebih lanjut Ismaun (2001: 114) mengemukakan bahwa tujuan pendidikan sejarah adalah agar peserta didik mampu memahami sejarah, memiliki kesadaran sejarah, dan memiliki wawasan sejarah yang bermuara pada kearifan sejarah. Begitu pula dengan pernyataan yang pernah diungkapkan oleh Presiden Sukarno bahwa "bangsa yang besar adalah bangsa yang selalu menghargai sejarah perjuangan bangsanya". Ungkapan yang begitu 
bijaksana mengandung pengertian yang sangat mendalam ini menunjukkan begitu pentingnya peranan pelajaran sejarah.Oleh karena peranan mata pelajaran sejarah di sekolah sangat penting, sehingga diharapkan dapat menjadi suatu mata pelajaran yang menarik karena mengajarkan kepada siswa berbagai peristiwa yang dialami oleh manusia dalam ruang dan waktu yang berbeda sehingga siswa dapat merasakan perubahan yang dialami oleh manusia dalam kehidupan.

Namun, berdasarkan temuan peneliti di kelas XI IPS 3, di SMA Negeri 1 Peyabungan, kenyataan yang dijumpai di lapangan menunjukkan proses pembelajaran Sejarah jauh dari harapan tersebut ditandai dengan rendahnya motivasi dan hasil belajar siswa untuk belajar sejarah. Adapun faktor yang menyebabkan hal tersebut diantaranya : sumber informasi belajar sepenuhnya berasal dari guru, guru kurang memberikan motivasi kepada siswa seseuai dengan tujuan pembelajaran yang akan dicapai, sehingga mempengaruhi hasil belajar siswa pada pelajaran sejarah, kurangnya alat peraga, dan metode yang digunakan tidak bervariasi sehingga siswa kurang aktif dalam pembelajaran. Dimana metode yang digunakan hanya ceramah dan hanya mengembangkan kemampuan berpikir siswa terhadap suatu materi, tetapi tidak merangsang kemauan dan semangat siswa untuk mengetahui berbagai hal ilmu pengetahuan.
Sementara, Kurikulum Tingkat Satuan Pendidikan (KTSP) menuntut guru untuk mengubah pola-pola pembelajarannya, yang semula berpusat pada guru, menjadi pembelajaran yang berfokus pada aktifitas siswa. Kurikulum juga menuntut perubahan peran siswa dari kebiasaannya sebagai pendengar pasif dan menunggu perintah guru menjadi siswa yang aktif, kreatif dan mampu berinisiatif serta mampu bersosialisasi antar sesamanya. Dengan demikian kegiatan pembelajaran yang berlangsung tidak menimbulkan kejenuhan kepada siswa akan tetapi dapat meningkatkan motivasi belajar dan semangat siswa, yang berakibat pada meningkatnya pemahaman siswa terhadap bidang studi sejarah sesuai dengan hasil yang diharapkan.

Oleh karena itu, untuk meningkatkan pemahaman dan hasil belajar siswa pada mata pelajaran Sejarah peneliti melakukan inovasi pembelajaran terhadap cara peneliti mengajar. Yaitu dari mengajar dengan metode Konvensional menjadi pembelajaran Talking Stick. Talking Stick termasuk salah satu model pembelajaran kooperatif. Pembelajaran Talking Stick ini sangat cocok untuk melatih siswa aktif berbicara karena Talking Stick mendorong siswa untuk berani mengemukakan pendapat.

Berdasarkan latar belakang masalah yang telah diuraikan tersebut, maka dapat diidentifikasi masalah yang relevan dengan penelitian ini, antara lain : 
a. Rendahnya minat belajar siswa terhadap mata pelajaran Sejarah.

b. Penyampaian materi yang monoton dan metode yang tidak efektif, peneliti (guru) cenderung menggunakan metode konvensional.

c. Siswa pasif pada saat proses belajar mengajar berlangsung.

d. Kurangnya penggunaan metode atau model yang bervariasi dalam pembelajaran yang diterapkan guru.

e. Pembelajaran cenderung terpusat pada guru.

Untuk menyelesaikan masalah-masalah yang dihadapi siswa, maka peneliti membatasi sesuai dengan kemampuan peneliti antara lain:

a. Menggunakan Model Pembelajaran Talking Stick selama kegiatan belajar mengajar.

b. Subjek penelitian adalah siswa kelas XI IPS 3 SMA Negeri 1 Penyabungan kabupaten Mandailing Natal Tahun Pembelajaran 2014/2015.

c. Materi yang diterapkan selama pengambilan data adalah Menganalisis Pengaruh Perkembangan Agama dan Kebudayaan Islam terhadap Masyarakat di Berbagai Daerah di Indonesia.

d. Kurikulum yang digunakan adalah KTSP.

Berdasarkan batasan masalah yang diuraikan diatas maka rumusanmasalahnya adalah : Apakah penerapan model pembelajaran Talking Stick dapat meningkatkan hasil belajar sejarah siswa kelas XI
IPS 3 SMA Negeri 1 Panyabungan Tahun Pembelajaran 2014/2015.

Adapun tujuan penelitian ini sejalan dengan rumusan masalah di atas yaitu: Untuk meningkatkan hasil belajar sejarah dengan menerapkan model pembelajaran Talking Stick siswa kelas XI IPS 3 SMA Negeri 1 Penyabungan Tahun Pembelajaran 2014/2015.

Adapun manfaat dari hasil penelitian ini adalah :

a. Untuk siswa :

- Membantu siswa meningkatkan hasil belajar dalam pembelajaran sejarah.

- Membantu siswa memahami konsep, kejadian, peristiwa, fakta, data dan interprestasi serta kebenaran sejarah.

b. Untuk Guru :

- Meningkatkan pengetahuan dan pengalaman tentang penelitan tindakan kelas

- Memotivasi untuk selalu eksplorasi dalam teknik, metode dan model pembelajaran yang kreatif serta inovatif dalam rangka meningkatkan hasil belajar siswa

- Menambah kepustakaan guru dalam pemilihan model pembelajaran.

c. Untuk Kepala Sekolah :

Sebagai bahan pertimbangan untuk menerapkan model tersebut untukguru-guru yang lain

\section{METODOLOGI PENELITIAN}

Lokasi penelitian dilakukan di SMA Negeri 1 Penyabungan, Kecamatan Panyabungan, Kabupaten 
Mandailing Natal, Provinsi Sumatera

Utara. Penelitian dilakukan pada semester ganjil selama 4 bulan (bulan Agustus s/d November) Tahun 2014. Materi Pembelajaran Sejarah yang digunakan selama pengambilan data adalah Menganalisis Pengaruh Perkembangan Agama dan Kebudayaan Islam terhadap Masyarakat di Berbagai Daerah di Indonesia.

Subjek penelitian ini adalah siswa kelas XI IPS 3 SMA Negeri 1 Penyabungan Tahun Pelajaran 2014/2015, dengan jumlah siswa sebanyak 35 orang.

Supaya tidak terjadi salah persepsi terhadap judul penelitian ini, maka perlu didefinisikan hal-hal sebagai berikut:

a) Hasil belajar adalah perubahan tingkah laku yang diperoleh pembelajar setelah mengalami aktivitas belajar.

b) Model Pembelajaran adalah suatu desain yang melukiskan prosedur sistematis untuk membantu peserta didik dalam mencapai tujuan pembelajaran.

c) Talking Stick (tongkat berbicara) merupakan model pembelajaran yang menggunakan media tongkat atau pembelajaran bermain tongkat, siapa yang megang tongkat wajib menjawab pertanyaan dari guru setelah siswa mempelajari materi pokoknya.

Dalam penelitian ini, peneliti menggunakan alat pengumpul data sebagai berikut: a) Tes

Tes adalah alat untuk memperoleh sejauh mana kemampuan kognitif siswa dan melihat tingkat keberhasilan siswa dari suatu materi ajar yang disampaikan.Tes yang digunakan yaitu tes tertulis yang berupa soal pilihan ganda. Dengan pilihan jawaban a, b, c, dan d. Tes ini dilakukan pada waktu evaluasi pembelajaran

b) Observasi

Observasi ini dilakukan dengan mengadakan pengamatan selama kegiatan pengajaran berlangsung. Teknik ini digunakan peneliti untuk mengumpulkan data berupa sikap dan tindakan dengan mengamati aktivitas siswa selama proses pembelajaran dengan menerapkan metode Talking Stick.

Untuk menganaslisis data, penelitian ini menggunakan metode deskriptif dengan membandingkan hasil belajar siswa sebelum tindakan dengan hasil belajar siswa setelah tindakan.

Langkah-langkah pengolahan data sebagai berikut:

a. Merekapitulasi nilai pretes sebelum tindakan dan nilai tes akhir siklus I dan siklus II.

b. Menghitung nilai rata-rata atau persentase hasil belajar siswa sebelum dilakukan tindakan dengan hasil belajar setelah dilakukan tindakan pada siklus I dan siklus II untuk mengetahui adanya peningkatan hasil belajar. 


\section{Penilaian}

a) Data nilai hasil belajar (kognitif) diperoleh dengan menggunakan rumus:

Nilai Siswa $=\frac{\text { Jumlah jawaban benar }}{\text { Jumlah seluruh soal }} \times 100$ (Slameto,2001:189)

b) Nilai rata-rata siswa dicari dengan rumus sebagai berikut:

$$
\bar{X}=\frac{\sum X}{N}
$$

(Subino, 1987:80)

Keterangan :

$\bar{X}=$ Nilai rata-rata

$\Sigma=$ Jumlah nilai $X$

$\mathrm{N}=$ Jumlah peserta tes

c) Ketentuan persentase ketuntasan belajar kelas

Ketuntasan belajar kelas $=\frac{\sum S_{b}}{K} \times 100 \%$

$\Sigma \mathrm{Sb}=$ Jumlah siswa yang mendapat

nilai $\geq 78$ (kognitif)

$\Sigma \mathrm{K}=$ Jumlah siswa dalam sampel

$$
\text { Desain yang digunakan }
$$

dalam penelitian ini adalah Penelitian Tindakan Kelas yang dilaksanakan dalam bentuk siklus yang terdiri dari dua siklus dengan empat tahap yaitu : Perencanaan (planning), Pelaksanaan (action), Pengamatan (observasi) dan refleksi (reflektion).

\section{Gambar 1. Alur Penelitian \\ Tindakan Kelas Arikunto dkk (2008:16)}

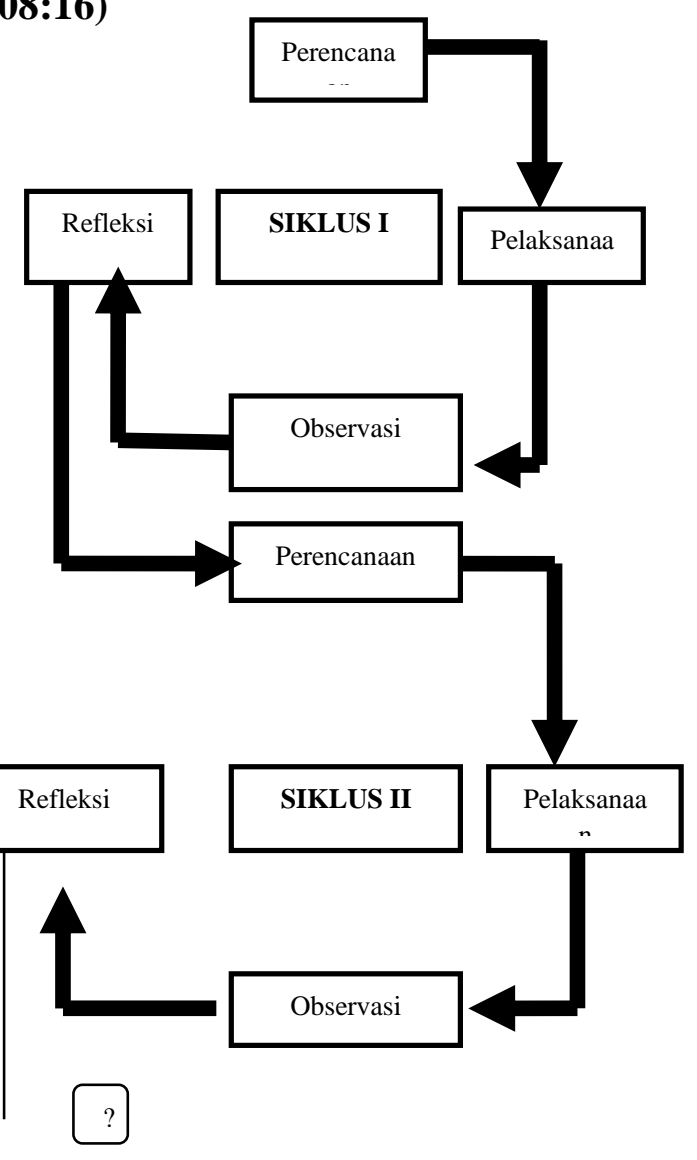

Penelitian ini dilakukan dalam beberapa tahap pelaksaanaan tindakan sebagai berikut:

\section{Siklus I}

\section{Perencanaan}

Tahap perencanaan ini dilakukan sebelum dilakukan pembelajaran siklus I, pada tahap ini kegiatan yang dilakukan adalah:Membuat Rencana Pelaksanaan Pembelajaran (RPP).

\section{Pelaksanaan tindakan}

Kegiatanyangdilakukan pada tahap ini adalah melaksanakan 
rencana pembelajaran yang telah direncanakan dalam RPP.Pelaksanaan setiap siklus adalah 2 kali pertemuan. Kegiatan tindakan meliputi:

a. Guru menjelaskan maksud dan tujuan pembelajaran.

b. Guru membagi siswa menjadi beberapa kelompok, dimana tiap kelompok terdiri atas 5 orang.

c. Guru menyampaikan materi pelajaran.

d. Siswa diberi kesempatan membaca dan mempelajari materi tersebut. Lalu siswa diminta untuk menutup bukunya.

e. Guru mengambil tongkat yang telah dipersiapkan sebelumnya.

f. Guru memberikan tes dengan memberikan tongkat kepadasalah satu anggota kelompok, setelah itu siswa diberikan pertanyaan dan anggota kelompok yang menerima tongkat tersebut diwajibkan menjawab pertanyaan dari guru demikian seterusnya.

\section{Pengamatan}

Pengamatan dilakukan untuk mengetahui kesesuaian tindakan dengan rencana yang telah ditetapkan sekaligus mengetahui sejauhmana tindakan dapat menghasilkanperubahan yang sesuai dengan yang dikehendaki.Pengamatan yang dilaksanakan meliputi : a. Kesesuaian urutan KBM yang direncanakan.

b. Keaktifan guru dalam mengelola KBM dalam kelas.

c. Keaktifan siswa dalam belajar

d. Memberikan dorongan belajar kepada siswa.

e. Memberikan peluang kepada siswa untuk melakukan tanya jawab.

\section{Refleksi.}

Kegiatan refleksi dilakukan dengan mempertimbangkan pedoman mengajar yang dilakukan serta melihat kesesuaian yang dicapai dengan yang diinginkan dalam pembelajaran yang pada akhirnya ditemukan kelebihan dan kekurangan, dimana jika ditemukan kekurangan akan dilakukan tindakan perbaikan pada siklus II. Setelah siklus I dijalankan dan hasil yang dicapai belum seperti yang diharapkan, maka dilakukan kembali tahap-tahap di atas untuk dilakukan pada siklus II dan siklus selanjutnya sampai hasil belajar yang diharapkan tercapai. Pelaksanaan siklus II dilakukan setelah melakukan perbaikan-perbaikan pada rencana pembelajaran dan tindakan yang akan dilakukan dengan urutan-urutan seperti yang dilaksanakan pada siklus I. Kegiatan refleksi dilakukan pada berbagai aspek yaitu;

a. Waktu yang digunakan.

b. Kesempatan belajar 
c. Pengelolaan bahan belajar

d. Partisipasi siswa dalam pembelajaran

e. Bagaimana mengeluarkan Pendapat

\section{Siklus II}

\section{Perencanaan (Planning)}

Tahap perencanaan tindakan ini dilakukan untuk melihat hasil belajar siswa setelah dilakukan tindakan pertama. Pada tahap ini kegiatan yang dilakukan berupa perbaikan skenario pembelajaran (RPP) yang disesuaikan hasil refleksi tindakan pada siklus I dengan langkah-langkah sebagai berikut:

a. Mengidentifikasi masalah yang muncul pada siklus I dan mencari alternatif pemecahan masalah.

b. Mengembangkan indikator pembelajaran.

c. Mengembangkan skenario pembelajaran.

d. Menentukan langkah-langkah yang akan dilakukan dalam kegiatan pembelajaran berdasarkan masalah yang ditemukan pada siklus I.

\section{Pelaksanaan Tindakan}

Kegiatan yang dilaksanakan dalam tahap ini adalah melaksanakan rencana pembelajaran yang telah direncanakan, berupa proses pembelajaran sesuai dengan rencana pembelajaran dan disesuaikan dengan hasil refleksi siklus I. Kegiatan ini diakhiri dengan pemberian tes kepada siswa. Adapun skenario pembelajaran yang dilakukan adalah:

a. Guru melakukan apersepsi.

b. Guru dan siswa melakukan tanya jawab tentang materi pelajaran yang disampaikan dengan media tongkat.

c. Guru membentuk kelompok diskusi seperti pada siklus I dan belajar sebagaimana pembelajaran Talking Stick pada siklus I.

d. Guru mengawasi aktivitas belajar yang dilakukan siswa.

e. Guru menyimpulkan hasil pembelajaran bersama siswa

f. Guru memberian tes hasil belajar

\section{Pengamatan}

Pengamatan yang dilaksanakan meliputi implementasi dalam monitoring pada proses pembelajaran di kelas secara langsung. Kegiatan yang diamati meliputi aktivitas guru dan siswa dalam pembelajaran.Pengamatan ini bertujuan untuk mengetahui kesesuaian tindakan dengan rencana yang telah disusun dan guna mengetahui sejauh mana pelaksanaan tindakan dapat menghasilkan perubahan hasil belajar yang lebih baik lagi.

\section{Refleksi}

Refleksi yang dilakukan pada tahap ini yaitu membandingkan hasil refleksi pada siklus I dengan siklus 
II. Dengan ini ternyata hasil belajar siswa selama mengikuti kegiatan pembelajaran apakah telah lebih baik dari siklus I.

Pada penelitian ini keberhasilan
yang ditetapkan adalah adanya
peningkatan daya serap siswa selama
pembelajaran yang dilihat dari hasil
belajar siswa. Keberhasilan penelitian
yang ditetapkan adalah jika telah
tercapai $85 \%$ siswa dalam kelas
mendapatkan nilai hasil belajar
mencapai KKM Sejarah $\geq 78$.Siswa
diharapkan aktif dalam pembelajaran
dengan mau mengemukakan pendapat,
bertanya dan juga menjawab pertanyaan
dari guru.

Penelitian ini dilaksanakan selama empat bulandari bulan Agustus sampai dengan bulan November 2014. Sebagai rinci jadwal pelaksanaan penelitian dapat di lihat dari tabel berikut .

\section{HASIL PENELITIAN DAN PEMBAHASAN}

Penelitian ini menggunakan pendekatan penelitian tindakan kelas, dimana kegiatan penelitian dilakukanuntuk mengambil sampel awal untuk melihat pengetahuan awal siswa serta kondisi siswa baik kelebihan maupun kekurangan siswa dalam proses pembelajaran agar bisa diambil suatu tindakan yang tepat untuk meningkatkan hasil belajar siswa. Dari hasil data awal tersebut menunjukan bahwa hanya 3 orang siswa yang mencapai Kriteria Ketuntasan Minimum (KKM), dimana KKM (Kriteria Ketuntasan
Minimum) untuk mata pelajaran Sejarah adalah 78. Hal ini terlihat dari nilai rata-rata yang diperoleh siswa masih cenderung rendah.

Berdasarkan data, dapat diketahui hasil tes awal terhadap hasil belajar dari 35 siswa hanya 3 orang siswa saja yang memperoleh hasil belajar yang mencapai standar kriteria ketuntasan maksimal (KKM) dengan batas ketuntasan 78 secara individual. Tabel di atas menunjukan bahwa 3 orang siswa yang tuntas dengan rincian 1 orang siswa mendapat 90 dan 2 orang siswa mendapatkan nilai 80. Sedangkan jumlah siswa yang tidak tuntas yaitu 33 orang siswa dengan nilai dibawah standar kriteria ketuntasan maksimal (KKM). Data pre test di atas, dapat dilukiskan dalam grafik sebagai berikut :

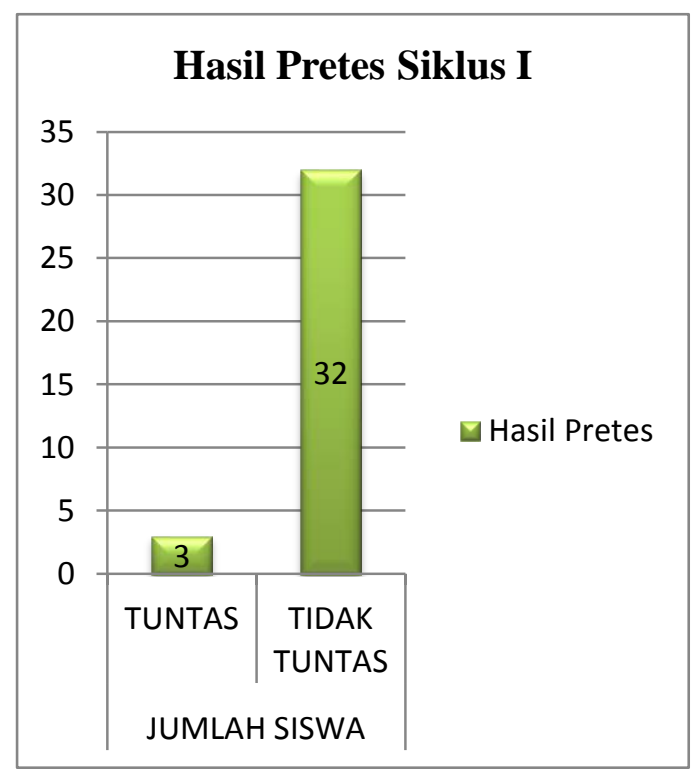




\section{Perencanaan Tindakan}

Pada tahap ini peneliti
mempersiapkan
perangkat pembelajaran yang terdiri dari RPP 1 dan 2 untuk kegiatan belajar mengajarpertemuan 1 dan pertemuan 2, soal Pretes dan Formatif 1 dan alat-alat pengajaran yang mendukung.

\section{Kegiatan dan Pelaksanaan}

Kegiatan siklus I pertemuan pertama dilakukan dari tanggal 7 Oktober 2014.Guru dalam hal ini bertindak sebagai peneliti. Siklus I pertemuan kedua dilakukan pada tanggal 14 Oktober 2014. Kegiatan pembelajaran dilakukan di kelas XI IPS 3 SMA Negeri 1 Panyabungan dengan siswa sebanyak 35 orang. Proses pembelajaran mengacu pada rancangan program pembelajaran. Berikut ini adalah rekaman proses pembelajaran KBM 1 dan KBM 2 :

\section{Skenario Pembelajaran KBM 1}

Pada tanggal 7 Oktober 2014, setelah bel sekolah dibunyikan menandakan bahwa pelajaran pertama akan segera dimulai. Seleruh siswa berlarian masuk ke kelas. Pada kegiatan awal, Pak Nuh mengucapkan salam, dan membaca do'a kemudian dilanjutkan dengan absensi dan mengecek kesiapan siswa. Lalu Pak Nuh menginformasikan materi yang akan dipelajari hari ini yaitu tentang "Proses lahir dan berkembangnya agama dan kebudayaan Islam.”

Lalu pak Nuh menyampaikan tujuan pembelajaran serta melakukan apersepsi tentang materi pembelajaran dengan menarik perhatian siswa sehingga menimbulkan motivasi, kehangatandan keantusisasan dalam belajar. Pak Nuh memberikan kesempatan kepada siswa untuk membaca dan mempelajari materi. Pak Nuh memberikan waktu untuk siswa membaca dan mempelajari sesuai dengan waktu yang telah ditentukan. Pak Nuh menyuruh siswa untuk menutup buku. Pak Nuh mengambil tongkat yang telah disediakan sebelumnya, lalu membagi siswa menjadi tujuh kelompok.

Tiap kelompok terdiri atas 5 orang dan memberikan tongkat serta LKS yang berisi pertanyaan kepada tiap kelompok. Kelompok yang mendapat tongkat harus menjawab pertanyaan yang diberikan pak Nuh. Pak Nuh kemudian memberikan kesempatan kepada kelompok lain untuk melakukan refleksi atau memberikan pendapat terhadap jawaban temannya. Pak Nuh memberikan ulasan terhadap seluruh jawaban yang diberikan. Pada kegiatan akhir, pak Nuh meminta siswa untuk menarik kesimpulan sendiri kemudian pak Nuh meluruskan kesimpulan yang diberikan siswa kemudian menutup pembelajaran dengan salam. 


\section{Skenario Pembelajaran KBM 2}

Pada tanggal 14 Oktober 2014, pada kegiatan awal setelah semua masuk ke dalam kelas, pak Nuh memulai pelajaran dengan mengucapkan salam, dan membaca do'a kemudian dilanjutkan dengan absensi dengan menanyakan kepada siswa apakah ada teman mereka yang tidak hadir dan mengecek kesiapan siswa. ternyata seluruh siswa hadir. Sebelum memulai materi baru, Pak Nuh menjelaskan kembali materi sebelumnya yang sudah dipelajari secara singkat. Lalu pak Nuh menyampaikantujuan pembelajaran serta melakukan apersepsi tentang materi pembelajaran dengan menarik perhatian siswa sehingga menimbulkan motivasi, kehangatan dan keantusisasan Pada kegiatan inti pak Nuh menjelaskan tentang materi "Pendapat para ahli tentang proses awal penyebaran Islam di kepulauan Indonesia dan Tempat-tempat dan bukti-bukti penyebaran awal Islam di Indonesia". dalam belajar.Kemudian pak Nuh memberikan kesempatan kepada siswa untuk membaca dan mempelajari materisesuai dengan waktu yang telah ditentukan.

Pak Nuh menyuruh siswa untuk menutup buku. Pak Nuh mengambil tongkat yang telah disediakan sebelumnya, lalu membagi siswa menjadi tujuh kelompok. Tiap kelompok terdiri atas 5 orang dan memberikan tongkat serta LKS yang berisi pertanyaan kepada tiap kelompok. Kelompok yang mendapat tongkat harus menjawab pertanyaan yang diberikan pak Nuh. Setelah berdiskusi dan menjawab pertanyaan, Pak Nuh meminta kelompok yang mendapatkan tongkat untuk mempersentasikan hasil jawaban mereka. Pak Nuh kemudian memberikan kesempatan kepada kelompok lain untuk melakukan refleksi atau memberikan pendapat terhadap jawaban temannya. Setelah itu, pak Nuh melakukan evaluasi kepada siswa, untuk mengukur hasil belajar siswa, dengan memberikan soal pilihan ganda untuk tes Formatif I.

Pada kegiatan akhir, pak Nuh memberikan kesempatan kepada siswa untuk bertanya tentang hal-hal yang belum dipahami dan menutup pembelajaran dengan salam.

\section{Pengamatan}

\section{Hasil Belajar pada Siklus I (Formatif I)}

Dari tahap kegiatan, setelah pertemuan kedua pada siklus I, kemudian dilakukan tes hasil belajar (Formatif I). Maka dari tes tersebut diperoleh data hasil belajar kognitif siswa pada siklus I sebagai berikut :

\section{Tabel 4.2. Hasil Belajar Siswa selama siklus I}

\begin{tabular}{|c|c|c|c|c|}
\hline Nilai & Frekuensi & $\begin{array}{c}\text { Rata - } \\
\text { rata }\end{array}$ & $\begin{array}{c}\text { S. } \\
\text { Deviasi }\end{array}$ & $\begin{array}{c}\text { K } \\
\text { Klasikal }\end{array}$ \\
\hline 50 & 1 & & & \\
\cline { 1 - 2 } 60 & 8 & & & \\
\cline { 1 - 2 } 70 & 6 & \multirow{2}{*}{73,71} & 10,31 & $57,14 \%$ \\
\cline { 1 - 2 } 80 & 17 & & & \\
\cline { 1 - 2 } 90 & 3 & & & \\
\cline { 1 - 2 } Jumlah & 35 & & & \\
\hline
\end{tabular}

Berdasarkan nilai pada Tabel 4.2 diatas, nilai terendah pada hasil formatif I (postes I) adalah 50 dan tertinggi adalah 90. Hasil ketuntasan nilai hasil belajar siswa secara individu yaitu sebanyak 20 orang siswa. 20 orang siswa tersebut telah tuntas mencapai batas KKM. 15 orang siswa lagi masih memperoleh nilai dibawah KKM yaitu dibawah 78. Dengan kriteria ketuntasan klasikal sebesar $85 \%$ maka ini berarti bahwa hasil belajar siswa tergolong rendah Formatif I ini disajikan dalam grafik histogram sebagai berikut: 


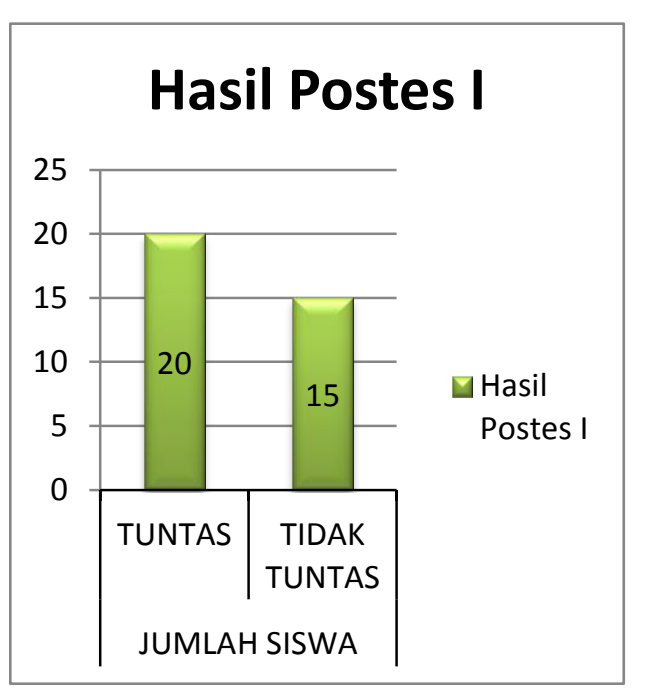

Gambar 4.2 Grafik Hasil Formatif I

Pada setiap pembelajaran pertemuan 1 dan pertemuan 2 pada siklus I, setiap peneliti melakukan proses pembelajaran maka peneliti berkolaborasi dengan rekan sejawat yang disebut sebagai Observer yang bertugas untuk mengamati aktivitas belajar siswa. Pengamatan aktivitas belajar siswa ini berpedoman pada lembar aktivitas belajar siswa yang telah disiapkan peneliti. Aktivitas belajar siswa siklus I dapat dilihat dalam tabel 4.3. berikut:

\begin{tabular}{|c|c|c|c|c|c|}
\hline \multirow{3}{*}{ No } & \multirow{3}{*}{ Aktivitas yang diamati } & \multicolumn{4}{|c|}{ Siklus II } \\
\hline & & \multicolumn{2}{|c|}{ Pertemuan 3} & \multicolumn{2}{|c|}{ Pertemuan 4} \\
\hline & & Jumlah & $\%$ & Jumlah & $\%$ \\
\hline 1. & $\begin{array}{l}\text { Siswa/kelompok } \\
\text { mendengarkan } \\
\text { penjelasan tentang } \\
\text { materi pokok yang akan } \\
\text { dipelajari }\end{array}$ & 35 & 100 & 35 & 100 \\
\hline 2. & $\begin{array}{l}\text { Siswa untuk membaca } \\
\text { dan } \\
\text { mempelajari materi } \\
\text { sesuai dengan waktu } \\
\text { yang telah ditentukan }\end{array}$ & 25 & 71,42 & 33 & 94,28 \\
\hline 3. & $\begin{array}{l}\text { Siswa/kelompok } \\
\text { menutup buku setelah } \\
\text { disuruh guru }\end{array}$ & 30 & 85,71 & 35 & 100 \\
\hline 4. & $\begin{array}{l}\text { Siswa/kelompok } \\
\text { mengambil tongkat yang } \\
\text { diberikan guru }\end{array}$ & 35 & 100 & 35 & 100 \\
\hline 5. & $\begin{array}{l}\text { Siswa/kelompok } \\
\text { menjawab } 1 \text { pertanyaan } \\
\text { yang diberikan guru }\end{array}$ & 20 & 57,14 & 30 & 85,71 \\
\hline 6. & $\begin{array}{l}\text { Siswa memberikan } \\
\text { refleksi atau } \\
\text { memberikan pendapat } \\
\text { terdapat jawaban } \\
\text { temannya }\end{array}$ & 8 & 22,85 & 15 & 42,85 \\
\hline & Jumlah & 153 & $72,85 \%$ & 183 & $87,14 \%$ \\
\hline
\end{tabular}

Data peningkatan aktivitas belajar siswa pada pertemuan ketiga dan keempat dapat dituliskan kembalikan pada grafik histogram sebagai berikut :

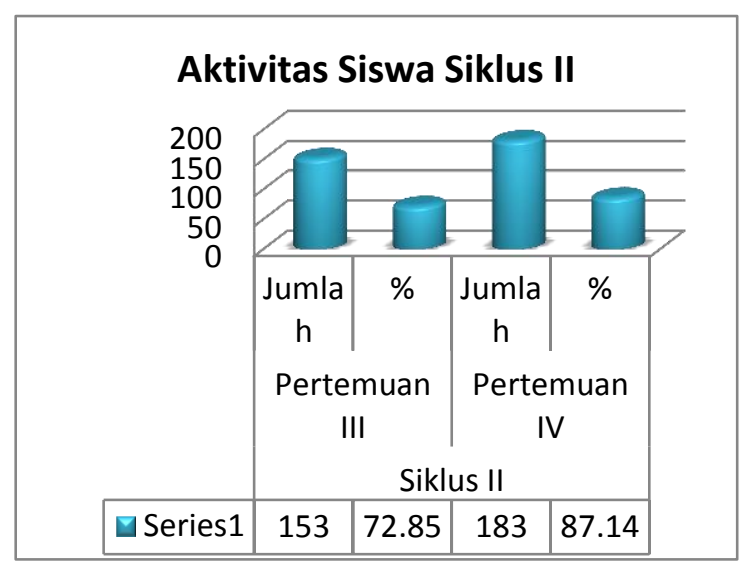


Gambar 4.5. Grafik Aktivitas Siswa Siklus II

Pembelajaran Siklus II relatif lebih baik dari pada Siklus I. Siswa mulai antusias mengikuti pembelajaran, beberapa siswa dapat mengikuti pembelajaran berkelompok dengan tertib dan siswa mulai banyak bertanya melalui teman dan kepada guru.

Tabel 4.6. Hasil belajar siswa saat Pretes, Formatif I dan Formatif II

\begin{tabular}{|c|l|c|c|c|}
\hline $\begin{array}{l}\text { N } \\
\text { o }\end{array}$ & Hasil Tes & $\begin{array}{c}\text { Data } \\
\text { Awal }\end{array}$ & $\begin{array}{c}\text { Siklus } \\
\text { I }\end{array}$ & $\begin{array}{c}\text { Siklus } \\
\text { II }\end{array}$ \\
\hline 1 & $\begin{array}{l}\text { Nilai } \\
\text { Tertinggi }\end{array}$ & 90 & 90 & 100 \\
\hline 2 & $\begin{array}{l}\text { Nilai } \\
\text { terendah }\end{array}$ & 30 & 50 & 70 \\
\hline 3 & $\begin{array}{l}\text { Rata-rata } \\
\text { nilai tes }\end{array}$ & 61,14 & 73,71 & 81,43 \\
\hline 4 & $\begin{array}{l}\text { Ketuntasan } \\
\text { klasikal }\end{array}$ & $9 \%$ & $57,14 \%$ & $\begin{array}{c}85,71 \\
\%\end{array}$ \\
\hline
\end{tabular}

Data pada tabel 4.6 dapat dituliskan kembali dalam histogram seperti gambar 4.6 berikut:

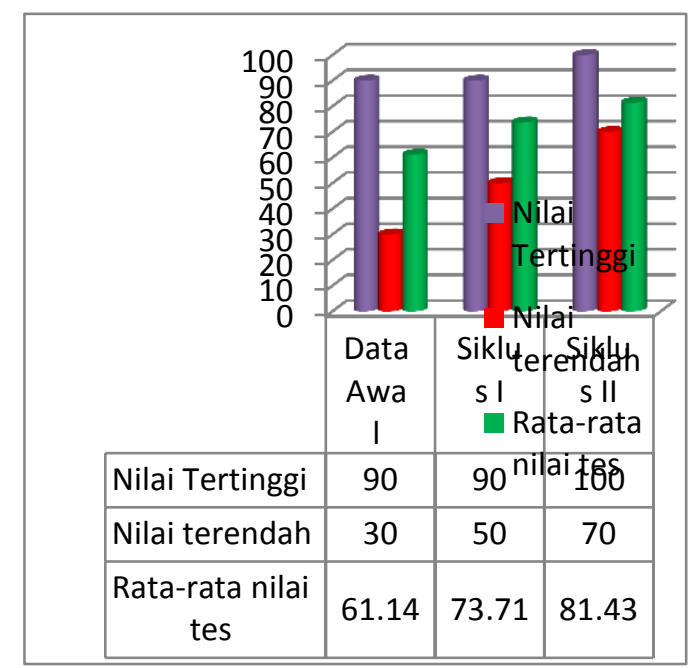

Gambar4.6. Hasil belajar siswa saat Pretes, Formatif I dan Formatif II

\section{Refleksi}

Setelah menerapkan Model Talking Stickdalam pembelajaran maka peneliti melakukan refleksi terhadap seluruh kegiatan pada siklus I :

a. Peneliti telah mampu meningkatkan dan memperbaiki kualitas pelaksanaan pembelajaran dengan menggunaka model Talking Stick

b. Siswa lebih giat menyelesaikan permasalahan yang ada dalam LKS

c. Suasana pembelajaran lebih kondusif, siswa mulai biasa belajar mandiri.

\section{Pembahasan}

Setelah

dilakukan

pembelajaran yang berimplementasi kurikulum berbasis kompetensi dengan model pembelajaran Talking Stick, diperoleh perubahan baik suasana kelas maupun kemampuan siswa dalam menyelesaikan LKS dan instrumen hasil belajar. Terjadi peningkatan aktivitas belajar siswa dan hasil belajar siswa dari siklus I kesiklus II.

Dari 35 orang jumlah siswa yang menjadi sampel dalam penelitian ini, dapat diketahui bahwa hasil belajar sejarah pada siklus I dan siklus II terus meningkat. Pada Formatif siklus I diketahui hasil belajar siswa belum maksimal karena 15 orang siswa belum tuntas belajar menurut Kriteria Ketuntasan Minimum (KKM), hanya 20 orang 
siswa dari 35 orang siswa yang tuntas belajar secara individu, dengan ketuntasan secara klasikal $57,14 \%$.

Maka dari itu pada hasil belajar pada siklus I beberapa perbaikan dilakukan pada pembelajaran siklus II, diantaranya dengan mendorong siswa untuk belajar mandiri dalam kelompok, kegiatan siswa yang tidak sesuai dengan KBM diawasi sehingga suasana belajar yang kondusif dalam kelas terwujud.

Dari hasil belajar pada siklus II, diketahui bahwa hasil belajar siswa lebih baik dari siklus sebelumnya. Dimana nilai terendah pada siklus II adalah 70. Sebanyak 30 orang siswa dari 35 orang siswa tuntas belajar menurut Kriteria Ketuntasan Minimum (KKM), dengan ketuntasan klasikal sebesar $85,71 \%$.

Melalui Talking Sticksiswa menjadi lebih bersemangat dalam mengikuti proses belajar. Dalam pembentukan kelompok guru menggunakan tongkat dan memberi pertanyaan pada setiap kelompok dan kelompok lain boleh memberikan tanggapan sehingga siswa lebih terpacu aktif dalam kelompok.

Dari pembahasan diatas dapat disimpulkan bahwa penerapan model pembelajaran

Talking

Stickdalambelajar sejarah di kelas XI IPS 3 Semester Ganjil SMA Negeri 1 Panyabungan tahun pembelajaran
2014/2015 terbukti dapat meningkatkan hasil belajar siswa.

\section{SIMPULAN DAN SARAN}

\section{Simpulan}

Berdasarkan hasil penelitian dan pembahasan maka dapat disimpulkan bahwa penerapan model pembelajaran kooperatif tipe Talking Stickdapat meningkatkan hasil belajar siswa kelas XI IPS 3 SMA Negeri 1 Panyabungan tahun pembelajaran 2014/2015. Hal ini terlihat dari hasil belajar siswa pada saat dilakukan Pretes hanya 3 orang siswa yang nilainya mencapai KKM. Lalu setelah diterapkan model pembelajaran Talking Stick, pada siklus I ketuntasan siswa meningkat menjadi 20 orang yang mencapai KKM dengan rata - rata 73,71 dan ketuntasan klasikal 57,14\%. Pada siklus II ketuntasan hasil belajar siswa semakin meningkat dengan nilai rata-rata 81,43 dan ketuntasan klasikal 85,71\%.

\section{Saran}

Dari hasil penelitian di atas agar proses belajar mengajar lebih efektif dan memberikan hasil yang optimal bagi siswa, maka disampaikan saran sebagai berikut:

1. Model pembelajaran kooperatif model Talking Stick dapat meningkatkan aktivitas dan hasil belajar siswa, oleh karena itu peneliti menyarankan para guru untuk menggunakan model pembelajaran tersebut khususnya saat pembelajaran Sejarah.

2. Bagi yang ingin melakukan penelitian lebih lanjut, peneliti 
menyarankan dapat melakukan penelitian dengan waktu yang lebih lama dengan sumber yang lebih luas. Agar dapat dijadikan studi perbandingan bagi guru dalam meningkatkan kualitas kajian khususnya pada bidang sejarah.

\section{DAFTAR RUJUKAN}

DepartemenPendidikan Nasional. (2006). Standar Isi Untuk Satuan Pendidikan Dasar Dan Menengah.Jakarta: Depdiknas

Hamalik, Huda . (2013). Modelmodel Pengajaran dan Pembelajaran.

Yogyakarta: Pustaka Pelajar.

Lamdari, H. S. (2012). Penerapan Metode Talking Stick Sebagai Upaya Meningkatkan
Pemahaman Konsep Kerja

Sama Negara-Negara Asia

Tenggara (ASEAN) pada

Siswakelas VI SD Negeri

II Jendi Girimarto

Wonogiri Tahun Pelajaran 2011/2012.

Lestari, S. (2012). Upaya Meningkatkan Aktivitas Belajar Siswa Menggunakan

Metode Talking Stick Pada Mata Pelajaran IPS Di SMP. Pontianak : FKIP Untan.

Suprijono, Agus. (2013). Cooperative

Learning. Yogyakarta: Pustaka Belajar.

Slavin, R.E. 2005. Cooperative Learning Teori, Riset dan Praktik. Bandung: Nusa Media. 